\title{
Risk Factors for Vitamin D Deficiency in Patients with Chronic Kidney Disease
}

\author{
Yoshihisa Echida, Toshio Mochizuki, Keiko Uchida, Ken Tsuchiya and Kosaku Nitta
}

\begin{abstract}
Objective We conducted a cohort study to identify the risk factors for vitamin D deficiency in predialyzed patients with chronic kidney disease (CKD).

Methods An observational study of 135 outpatients with stage 3-5 CKD was undertaken. Clinical and biochemical parameters were analyzed in terms of nutritional status, inflammation, and mineral metabolism in relation to serum levels of 25-hydroxyvitamin D [25(OH)D]. Levels of $25(\mathrm{OH}) \mathrm{D}$ lower than $15 \mathrm{ng} / \mathrm{mL}$ were considered to be deficient.

Results The 25(OH)D-deficient group had a higher body mass index $\left(24.1 \pm 4.2 \mathrm{~kg} / \mathrm{m}^{2}\right.$ vs. $22.5 \pm 4.0 \mathrm{~kg} / \mathrm{m}^{2}$, $\mathrm{p}=0.0322)$, and had more diabetic patients $(27.9 \%$ vs. $3.6 \%, \mathrm{p}=0.0003)$. The multivariate analysis revealed that body mass index (odds ratio $=2.758 ; 95 \% \mathrm{CI}, 1.048-7.721 ; \mathrm{p}=0.0398$ ), the presence of diabetes (odds ratio $=7.792 ; 95 \% \mathrm{CI}, 1.808-55.439 ; \mathrm{p}=0.0043$ ), lower hemoglobin concentration (odds ratio $=0.297 ; 95 \% \mathrm{CI}$, 0.099-8.732; $\mathrm{p}=0.821$ ), higher serum levels of non-HDL cholesterol (odds ratio=3.570; 95\% CI, 1.449-9.442; $\mathrm{p}=0.0053$ ) and triglyceride (odds ratio $=2.447 ; 95 \% \mathrm{CI}, 0.779-1.776 ; \mathrm{p}=0.0258$ ) were the factors associated with low 25(OH)D levels.

Conclusion Vitamin D deficiency was common among the predialysis CKD patients, and the factors identified as being associated with vitamin D deficiency were diabetes and obesity.
\end{abstract}

Key words: chronic kidney disease, vitamin D deficiency, obesity, diabetes

(Intern Med 51: 845-850, 2012)

(DOI: 10.2169/internalmedicine.51.6897)

\section{Introduction}

Low 25-hydroxyvitamin D [25(OH)D] levels are common in patients with chronic kidney disease (CKD), and the prevalence of this condition increases as kidney function declines $(1,2)$. Several factors, including increasing age and comorbid conditions, such as diabetes and hypertension, have consistently been associated with low 25(OH)D levels in individuals with both dialysis-dependent and nondialysisdependent CKD $(3,4)$. Analysis of the data obtained in the Third National Health and Nutrition Examination Survey (NHANES) conducted in the United States showed an inverse association between the body mass index (BMI) and 25(OH)D levels of persons with CKD (5), but a longitudinal study found no such association (6).

Evidence linking low 25(OH)D levels and cardiovascular risk factors in nondialysis-dependent CKD patients has been accumulating in recent years (7). The NHANES analyses reported a positive association between low 25(OH)D levels and the mortality of persons with CKD defined as either an estimated glomerular filtration rate (eGFR) $<60 \mathrm{~mL} / \mathrm{min} /$ $1.73 \mathrm{~m}^{2}$ or the presence of microalbuminuria (5). Similarly, a single-center study by Ravani et al. reported independent associations between low 25(OH)D levels and all-cause mortality (6). However, another community-based study did not find any association between 25(OH)D levels and cardiovascular mortality in community-dwelling adults (8). In the present study, we attempted to identify factors associated with low 25(OH)D levels in patients with stages 3 to 5 CKD who had been followed up in our outpatient clinic.

Department of Medicine, Kidney Center, Tokyo Women's Medical University, Japan 


\section{Materials and Methods}

\section{Study population}

This was a cross-sectional cohort study. We analyzed data in our electronic health record-based CKD registry. The development and validation of an electronic health recordbased CKD registry at the Kidney Center of Tokyo Women's Medical University has been described in detail elsewhere (9). Patients who met the following inclusion criteria as of September 1, 2006, were included in the CKD registry: patients who had 2 estimated glomerular filtration rate (eGFR) values $<60 \mathrm{~mL} / \mathrm{min} / 1.73 \mathrm{~m}^{2}$ using the modification of diet in renal disease (MDRD) study equation for Japanese people (10). Patients under 20 years of age and patients already diagnosed with end-stage renal disease (ESRD) that required renal replacement therapy were excluded, and patients who had an active infection, severe cardiovascular disease, or ascites with liver disease were also excluded. Patients who met the inclusion/exclusion criteria were included in the analysis. The underlying renal diseases of the patients who were included in the study were diabetic nephropathy $(n=24)$ and nephropathy of non-diabetic origin $(n=111)$. The Institutional Research Ethics Committee approved the study protocol, and all patients signed an informed consent form. This study was conducted in compliance with the Declaration of Helsinki.

The CKD registry contains patients' demographic information, prescribed medications, laboratory data, and information about their treatment. Blood pressure was measured with a brachial sphygmomanometer three times after the subject had rested in the supine position for at least $10 \mathrm{~min}$ utes, and the average value of the three measurements was adopted. Body mass index (BMI) was calculated by dividing body weight $(\mathrm{kg})$ by body height $(\mathrm{m})^{2}$. Prescribed doses of oral vitamin D analogue (alfacalcidol) were recorded. Alfacalcidol was administered when serum calcium was less than $8.5 \mathrm{mg} / \mathrm{dL}$ and serum intact parathyroid hormone (PTH) higher than $150 \mathrm{pg} / \mathrm{mL}$ after titration with $\mathrm{CaCO}$.

\section{Laboratory parameters}

Fasting blood specimens were collected to measure blood chemistry parameters. Serum albumin, aspartate aminotransferase (AST), alanine aminotransferase (ALT), calcium, phosphorus, total cholesterol, high-density lipoprotein (HDL) cholesterol, triglyceride, alkaline phosphatase, glucose, and C-reactive protein (CRP), and hemoglobin concentrations were measured by routine laboratory methods. Lowdensity lipoprotein (LDL) cholesterol values were calculated by using the Friedewald formula. The non-HDL cholesterol value was calculated by subtracting the HDL cholesterol value from the total cholesterol value. Serum intact parathyroid hormone $(\mathrm{PTH})$ was measured once. Serum 25(OH)D was measured by radioimmunoassay (DiaSorin Inc., Stillwater, MN, USA) at a commercial clinical laboratory (SRL,
Tokyo, Japan). Five blinded quality-control samples were included in the batch analysis; the coefficient of variation for $25(\mathrm{OH}) \mathrm{D}$ was $33.3 \%$. The coefficients of intra- and interday variation of routine quality-control data for $25(\mathrm{OH}) \mathrm{D}$ reported by SRL ranged between $4.3 \%$ and $7.0 \%$ (mean levels of $8.5,14.1$, and $50.9 \mathrm{ng} / \mathrm{mL}$ ).

\section{Statistical analysis}

The variables with a normal distribution were expressed as means $\pm \mathrm{SD}$, and those that did not have a normal distribution were expressed as medians and 25-75 percentiles. Categorical variables were expressed as numbers and percentages. Comparisons between continuous variables were performed by using the Mann-Whitney U test. The KruskalWallis test was used for comparisons of more than two groups. Categorical variables were compared using the chi square test. Spearman's bivariate correlation was used to assess the strength of the associations between the analyzed data and the $25(\mathrm{OH}) \mathrm{D}$ levels. Statistically significant variables were selected as potential independent predictors of 25 $(\mathrm{OH}) \mathrm{D}$ deficiency in the multivariate binary logistic regression analysis, with the dependent variable being the presence or absence of $25(\mathrm{OH}) \mathrm{D}$ deficiency. All of the statistical data analyses were conducted with the JMP, version 9.1 software program (SAS Institute Japan, Tokyo, Japan). The protocol of this study was approved by the Institutional Review Board of Tokyo Women's Medical University.

\section{Results}

\section{Patient characteristics}

The distribution of the 135 patients according to CKD stage was: stage 3, 68 patients $(50.4 \%)$; stage 4,48 patients (35.6\%); and stage 5, 19 patients (14.0\%). The clinical and biochemical data of the 135 patients are shown in Table 1. As shown in Fig. 1, the serum 25(OH)D levels of the patients with stage 3,4 , and $5 \mathrm{CKD}$ expressed as the median value and interquartile range were: stage $3,13.6 \mathrm{ng} / \mathrm{mL}$ (9.5-21.8); stage 4, $12.9 \mathrm{ng} / \mathrm{mL}$ (7.7-18.3); and stage 5, 13.0 $\mathrm{ng} / \mathrm{mL}$ (9.5-20.2). The serum 25(OH)D levels tended to decrease with the stage of the CKD, but the differences in values between the stages did not reach the levels of statistical significance $(\mathrm{p}=0.6789)$. No patient had abnormal liver function.

Table 2 compares the data analyzed in relation to serum $25(\mathrm{OH}) \mathrm{D}$ levels above and below the cut-off point of $15 \mathrm{ng} /$ $\mathrm{mL}$. The $25(\mathrm{OH}) \mathrm{D}$-deficient group had a higher BMI $(24.1 \pm$ $4.2 \mathrm{~kg} / \mathrm{m}^{2}$ vs. $22.5 \pm 4.0 \mathrm{~kg} / \mathrm{m}^{2}, \mathrm{p}=0.0322$ ), and had more diabetic patients $(27.9 \%$ vs. $3.6 \%, \mathrm{p}=0.0003)$. There was no significant difference in fasting blood glucose levels between the two groups $(98.8 \pm 23.8 \mathrm{mg} / \mathrm{dL}$ vs. $96.2 \pm 26.7 \mathrm{mg} / \mathrm{dL})$. Lower hemoglobin concentrations and higher serum levels of non-HDL cholesterol and triglyceride were detected in the $25(\mathrm{OH}) \mathrm{D}$-deficient group. There were no differences between the groups in renal function, assessed on the basis of 
Table 1. Clinical and Biochemical Characteristics of Study Population

\begin{tabular}{lc}
\hline Variable & $\mathrm{n}=135$ \\
\hline Age (years) & $60.5 \pm 12.7$ \\
Men (\%) & $72(53 \%)$ \\
Body mass index $\left(\mathrm{kg} / \mathrm{m}^{2}\right)$ & $23.4 \pm 4.2$ \\
Diabetes & $24(18 \%)$ \\
Systolic blood pressure (mmHg) & $124.3 \pm 12.3$ \\
Diastolic blood pressure (mmHg) & $73.3 \pm 9.4$ \\
Pulse pressure (mmHg) & $51.0 \pm 10.7$ \\
Calcium (mg/dL) & $9.0 \pm 0.5$ \\
25(OH)D (ng/mL) & $13.0(8.7-19.9)$ \\
Phosphorus (mg/dL) & $3.5 \pm 0.8$ \\
Alkaline phosphatase (U/L) & $217.9 \pm 80.6$ \\
Intact-PTH (pg/mL) & $102(72-142)$ \\
Albumin (g/dL) & $4.0 \pm 0.4$ \\
C-reactive protein (mg/L) & $0.7(0.5-1.4)$ \\
Creatinine (mg/dL) & $2.0 \pm 0.9$ \\
eGFR (mL/min/1.73m $\left.{ }^{2}\right)$ & $29.6 \pm 11.6$ \\
Proteinuria (g/gCr) & $0.57(0.18-1.36)$ \\
Hemoglobin (g/dL) & $12.3 \pm 1.9$ \\
Total cholesterol (mg/dL) & $196.2 \pm 48.0$ \\
HDL-cholesterol (mg/dL) & $52.6 \pm 17.2$ \\
Non-HDL-cholesterol (mg/dL) & $142.2 \pm 43.8$ \\
LDL-cholesterol (mg/dL) & $110.5 \pm 3.0$ \\
Triglyceride (mg/dL) & $157.9 \pm 89.3$ \\
Aspartate aminotransferase (IU/L) & $18.1 \pm 4.3$ \\
Alanine aminotransferase (IU/L) & $17.0 \pm 5.7$ \\
Glucose (mg/dL) & $97.7 \pm 25.0$ \\
Treatment with ACEI or ARB & $100(74 \%)$ \\
Treatment with statin & $52(39 \%)$ \\
Treatment with ESA & $24(18 \%)$ \\
Treatment with Vitamin D & \\
\hline
\end{tabular}

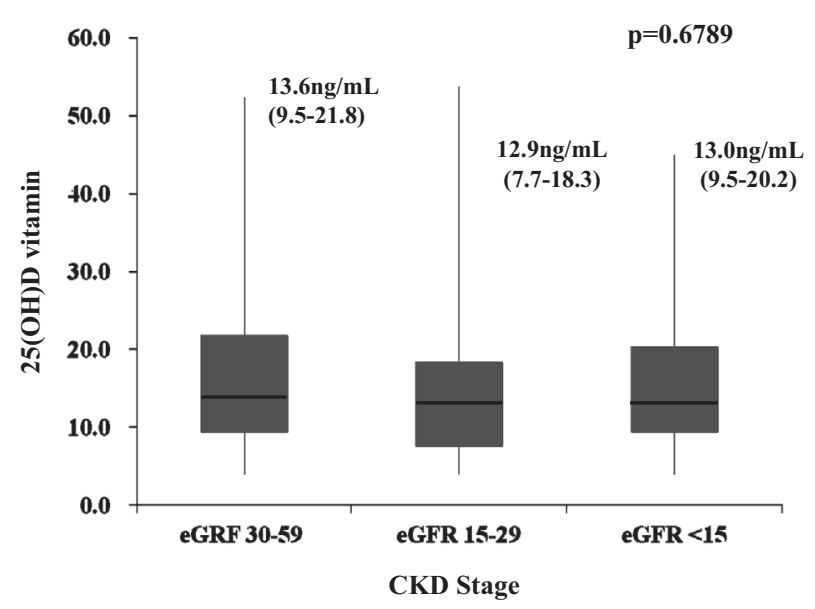

Figure 1. Serum 25(OH)D levels of the subjects with stage 3-5 chronic kidney disease (CKD).

the serum creatinine and eGFR values. Proteinuria (g/g creatinine) in spot urine samples tended to be higher in the 25 $(\mathrm{OH}) \mathrm{D}$-deficient group, but the difference did not reach the levels of statistical significance $(\mathrm{p}=0.0520)$. The results for mineral metabolism showed no significant differences between the two groups in the serum levels of calcium, phosphorus, alkaline phosphatase, and intact PTH or the prevalence of vitamin $\mathrm{D}$ therapy or dose of alfacalcidol $(0.7 \pm 1.2$ $\mu \mathrm{g} /$ week vs. $0.5 \pm 0.9 \mu \mathrm{g} /$ week, $\mathrm{p}=0.3148)$. The results for the nutritional parameters, i.e., serum albumin levels $(4.0 \pm 0.4 \mathrm{~g} /$ $\mathrm{dL}$ vs. $4.1 \pm 0.4 \mathrm{~g} / \mathrm{dL}, \mathrm{p}=0.0542$ ) showed no significant difference between the two groups in serum $25(\mathrm{OH}) \mathrm{D}$ levels. The inflammatory state according to the CRP levels showed no significant difference between the two groups in serum $25(\mathrm{OH}) \mathrm{D}$ levels $(4.0 \pm 0.4 \mathrm{mg} / \mathrm{L}$ vs. $4.1 \pm 0.4 \mathrm{mg} / \mathrm{L}, \mathrm{p}=$ $0.0542)$.

\section{Factors associated with low 25(OH)D levels}

The results of the univariate analysis (Table 3) showed that the serum $25(\mathrm{OH}) \mathrm{D}$ levels were inversely correlated with BMI $(\mathrm{r}=-0.218, \mathrm{p}=0.0114)$ and the serum triglyceride levels $(\mathrm{r}=-0.182, \mathrm{p}=0.0354)$, and that the serum 25(OH)D levels were positively correlated with age $(\mathrm{r}=0.286, \mathrm{p}=$ $0.0310)$, serum calcium levels $(r=0.221, p=0.0118)$, and hemoglobin concentrations $(\mathrm{r}=0.184, \mathrm{p}=0.0333)$. There was no significant association between the serum 25(OH)D levels and alfacalcidol dose $(\mathrm{r}=-0.121, \mathrm{p}=0.1660)$.

A logistic regression model was used to evaluate independent factors associated with low 25(OH)D levels. The multivariate analysis (Table 4) revealed that BMI (odds ratio $=2.758 ; 95 \% \mathrm{CI}, 1.048-7.721 ; \mathrm{p}=0.0398)$, the presence of diabetes (odds ratio=7.792; 95\% CI, 1.808-55.439; $\mathrm{p}=$ 0.0043 ), lower hemoglobin concentrations (odds ratio= 0.297; 95\% CI, 0.099-0.821; $\mathrm{p}=0.0188$ ), higher serum levels of non-HDL cholesterol (odds ratio=3.570; 95\% CI, 1.4499.442; $\mathrm{p}=0.0053$ ) and triglyceride (odds ratio $=2.447 ; 95 \%$ $\mathrm{CI}, 1.028-5.997 ; \mathrm{p}=0.0431)$ were the independent factors associated with low $25(\mathrm{OH}) \mathrm{D}$ levels.

\section{Discussion}

The risk factors for vitamin D deficiency in CKD patients have never been clearly identified. The results of this study showed a high prevalence of vitamin D deficiency in nondialyzed CKD patients, and we demonstrated that diabetes and obesity were the factors most closely associated with this condition.

In CKD patients, 25(OH)D deficiency is associated with age, the same as it is in the general population (11). This finding could be explained by a combination of factors, including poor nutrition, gastrointestinal disorders, or a lack of vitamin D synthesis because of little exposure to sun light. Dietary restriction and loss of appetite due to uremia may be strong determinants of $25(\mathrm{OH}) \mathrm{D}$ deficiency in CKD patients (2). The nutritional parameters analyzed in this study did not differ according to patients' $25(\mathrm{OH}) \mathrm{D}$ levels, so they may not be considered as a global malnutrition marker.

BMI was higher in the patient group with low $25(\mathrm{OH}) \mathrm{D}$ levels in this study, and obesity was associated with low 25 $(\mathrm{OH}) \mathrm{D}$. Several studies in the general population have shown a high prevalence of vitamin $\mathrm{D}$ deficiency in obese subjects $(12,13)$, and an increase in the serum $25(\mathrm{OH}) \mathrm{D}$ levels of obese patients has been observed after weight reduction (14). In CKD, the vitamin D deficiency in the spec- 
Table 2. Comparison of Clinical and Biochemical Data Regarding 25(OH)D Levels

\begin{tabular}{|c|c|c|c|}
\hline Clinical and analytical data & $\begin{array}{c}25(\mathrm{OH}) \mathrm{D} \\
\geq 15 \mathrm{ng} / \mathrm{mL} \\
\mathrm{n}=56(41 \%)\end{array}$ & $\begin{array}{c}25(\mathrm{OH}) \mathrm{D} \\
<15 \mathrm{ng} / \mathrm{mL} \\
\mathrm{n}=79(59 \%)\end{array}$ & $\mathrm{p}$ value \\
\hline Age (years) & $62.1 \pm 12.3$ & $59.4 \pm 13.0$ & 0.2261 \\
\hline Men $(\%)$ & $30 / 56(53.6)$ & $42 / 79(53.2)$ & 0.9628 \\
\hline Body mass index $\left(\mathrm{kg} / \mathrm{m}^{2}\right)$ & $22.5 \pm 4.0$ & $24.1 \pm 4.2$ & 0.0322 \\
\hline Diabetes & $2 / 56(3.6)$ & $22 / 79(27.9)$ & 0.0003 \\
\hline Systolic blood pressure (mmHg) & $124.1 \pm 12.3$ & $124.4 \pm 12.4$ & 0.8824 \\
\hline Diastolic blood pressure (mmHg) & $73.4 \pm 8.3$ & $73.2 \pm 10.1$ & 0.8577 \\
\hline Pulse pressure (mmHg) & $50.7 \pm 11.6$ & $51.1 \pm 10.1$ & 0.8394 \\
\hline Calcium (mg/dL) & $9.1 \pm 0.5$ & $8.9 \pm 0.5$ & 0.0537 \\
\hline Phosphorus (mg/dL) & $3.6 \pm 1.0$ & $3.3 \pm 0.6$ & 0.0729 \\
\hline Alkaline phosphatase (U/L) & $219.9 \pm 67.4$ & $216.4 \pm 89.2$ & 0.8095 \\
\hline Intact-PTH (pg/mL) & $87(67-128)$ & $105(74-154)$ & 0.0701 \\
\hline Albumin (g/dL) & $4.1 \pm 0.4$ & $4.0 \pm 0.4$ & 0.0542 \\
\hline CRP (mg/L) & $0.7(0.5-1.2)$ & $0.8(0.5-1.6)$ & 0.2195 \\
\hline Creatinine (mg/dL) & $1.9 \pm 0.9$ & $2.1 \pm 1.0$ & 0.3929 \\
\hline eGFR $\left(\mathrm{mL} / \mathrm{min} / 1.73 \mathrm{~m}^{2}\right)$ & $30.5 \pm 10.9$ & $28.9 \pm 12.1$ & 0.4161 \\
\hline Proteinuria (g/gCr) & $0.45(0.11-0.96)$ & $0.68(0.20-2.13)$ & 0.0520 \\
\hline Hemoglobin (g/dL) & $12.7 \pm 1.7$ & $12.0 \pm 2.0$ & 0.0324 \\
\hline Total cholesterol (mg/dL) & $189.0 \pm 47.1$ & $201.3 \pm 48.3$ & 0.1420 \\
\hline HDL-cholesterol (mg/dL) & $53.4 \pm 16.1$ & $52.1 \pm 18.0$ & 0.6482 \\
\hline Non-HDL-cholesterol (mg/dL) & $133.3 \pm 41.3$ & $148.5 \pm 44.8$ & 0.0465 \\
\hline LDL-cholesterol (mg/dL) & $104.8 \pm 33.9$ & $114.6 \pm 42.1$ & 0.1505 \\
\hline Triglyceride (mg/dL) & $138.6 \pm 74.6$ & $171.5 \pm 96.5$ & 0.0345 \\
\hline Aspartate aminotransferase (IU/L) & $18.6 \pm 4.4$ & $17.8 \pm 4.2$ & 0.2851 \\
\hline Alanine aminotransferase (IU/L) & $17.4 \pm 5.0$ & $16.8 \pm 6.2$ & 0.5470 \\
\hline Glucose (mg/dL) & $96.2 \pm 26.7$ & $98.8 \pm 23.8$ & 0.5618 \\
\hline Treatment with ACEI or ARB & $41 / 56$ & $59 / 79$ & 0.8478 \\
\hline Treatment with statin & $19 / 56$ & $33 / 79$ & 0.3562 \\
\hline Treatment with ESA & $6 / 56$ & $18 / 79$ & 0.0707 \\
\hline Treatment with Vitamin D & $13 / 56$ & $20 / 79$ & 0.7795 \\
\hline
\end{tabular}

trum of obesity has not been fully explored, and the cause of the relationship between obesity and vitamin D deficiency is not well known. Although this finding may be attributable to the low exposure of obese individuals to sunlight, one of the most widely accepted ideas is that because vitamin D is a fat-soluble substance, it can easily be sequestered and stored in adipose tissue and then slowly released as needed (15).

Diabetes was independently associated with vitamin D deficiency in our patients. There is increasing evidence that vitamin D is involved in the pathophysiology of insulin resistance, diabetes, and metabolic syndrome $(16,17)$. There are several lines of evidence supporting a role of vitamin D in pancreatic $\beta$-cell function (18). It seems that vitamin D stimulates pancreatic insulin secretion by increasing the ability of $\beta$-cells to synthesize insulin and accelerating the conversion of proinsulin to insulin (16). Vitamin D directly stimulates insulin receptor expression, thereby increasing the insulin response to glucose stimulation, and it indirectly stimulates insulin receptor expression by regulating the intracellular calcium concentration. Thus, it seems that both insulin resistance and type 2 diabetes are mediated by involving the mechanisms of $25(\mathrm{OH}) \mathrm{D}$ deficiency (18).

$25(\mathrm{OH}) \mathrm{D}$ deficiency is associated with higher mortality in
CKD and non-CKD populations, and various mechanistic links have been proposed to explain the associations (19-21), including suppression of the reninangiotensin-aldosterone system, cardiac myocyte hypertrophy, and vascular calcification. Analyses of NHANES III study that included data obtained from patients with a low eGFR and albuminuria, of which $70 \%$ of their study participants had stage 1 and $2 \mathrm{CKD}$, showed a similar increase in risk of all-cause mortality associated with $25(\mathrm{OH}) \mathrm{D}$ levels < $15 \mathrm{ng} / \mathrm{mL}$ (5). A single-center study reported higher risks of progression of kidney disease and death in stage 2-5 CKD patients who had low 25(OH)D levels (6). However, a recent study reported a lack of association between $25(\mathrm{OH}) \mathrm{D}$ level and cardiovascular mortality (8). A prospective study is needed to determine the role of vitamin $\mathrm{D}$ deficiency in CKD progression and mortality in CKD patients.

The present study had several limitations. The sample size was small, and despite careful adjustments in our statistical analyses, it was impossible to rule out the presence of residual confounding factors in relation to vitamin D deficiency. Second, there was attrition bias, because we included only patients whose serum $25(\mathrm{OH}) \mathrm{D}$ level had been measured. We therefore adjusted for several potential confounding variables in this analysis. Third, we cannot rule out an effect of 
Table 3. Spearman Bivariate Correlation between 25(OH)D Levels and Variables Studied

\begin{tabular}{lcc}
\hline Variable & Rho & p value \\
\hline Age (years) & 0.186 & 0.0310 \\
Body mass index $\left(\mathrm{kg} / \mathrm{m}^{2}\right)$ & -0.218 & 0.0114 \\
Systolic blood pressure $(\mathrm{mmHg})$ & -0.041 & 0.6373 \\
Diastolic blood pressure $(\mathrm{mmHg})$ & -0.027 & 0.7582 \\
Pulse pressure $(\mathrm{mmHg})$ & -0.044 & 0.6140 \\
Calcium $(\mathrm{mg} / \mathrm{dL})$ & 0.221 & 0.0118 \\
Phosphorus $(\mathrm{mg} / \mathrm{dL})$ & 0.104 & 0.2301 \\
Alkaline phosphatase $(\mathrm{U} / \mathrm{L})$ & 0.004 & 0.9660 \\
Intact-PTH (pg/mL) & -0.148 & 0.0875 \\
Albumin $(\mathrm{g} / \mathrm{dL})$ & 0.094 & 0.2779 \\
C-reactive protein $(\mathrm{mg} / \mathrm{L})$ & 0.019 & 0.8221 \\
Creatinine $(\mathrm{mg} / \mathrm{dL})$ & -0.063 & 0.4686 \\
eGFR $\left(\mathrm{mL} / \mathrm{min} / 1.73 \mathrm{~m}{ }^{2}\right)$ & 0.072 & 0.4024 \\
Proteinuria $(\mathrm{g} / \mathrm{gCr})$ & -0.165 & 0.0566 \\
Hemoglobin $(\mathrm{g} / \mathrm{dL})$ & 0.184 & 0.0333 \\
Total cholesterol $(\mathrm{mg} / \mathrm{dL})$ & -0.106 & 0.2195 \\
HDL-cholesterol $(\mathrm{mg} / \mathrm{dL})$ & 0.043 & 0.6218 \\
Non-HDL-cholesterol $(\mathrm{mg} / \mathrm{dL})$ & -0.122 & 0.1582 \\
LDL-cholesterol $(\mathrm{mg} / \mathrm{dL})$ & -0.071 & 0.4124 \\
Triglyceride $(\mathrm{mg} / \mathrm{dL})$ & -0.182 & 0.0354 \\
Aspartate aminotransferase $(\mathrm{IU} / \mathrm{L})$ & 0.094 & 0.2779 \\
Alanine aminotransferase $(\mathrm{IU} / \mathrm{L})$ & 0.094 & 0.2745 \\
Glucose $(\mathrm{mg} / \mathrm{dL})$ & -0.127 & 0.1423 \\
Alfacalcidol $(\mu \mathrm{g} / \mathrm{week})$ & -0.121 & 0.1660 \\
\hline & & \\
& & \\
\hline
\end{tabular}

Table 4. Logistic Regression Multivariate Analysis: Potential Predictors of Vitamin 25(OH)D Deficiency

\begin{tabular}{lccc}
\hline Independent variables & Odds ratio & $95 \%$ CI & p value \\
\hline Age $>60$ years & 0.497 & $0.195-1.221$ & 0.1280 \\
Sex $($ men) & 1.472 & $0.562-3.965$ & 0.4326 \\
Body mass index $>25 \mathrm{~kg} / \mathrm{m}^{2}$ & 2.758 & $1.048-7.721$ & 0.0398 \\
Diabetes & 7.792 & $1.808-55.439$ & 0.0043 \\
Calcium $>8.9 \mathrm{mg} / \mathrm{dL}$ & 0.532 & $0.209-1.315$ & 0.1718 \\
Phosphorus $>3.4 \mathrm{mg} / \mathrm{dL}$ & 0.502 & $0.204-1.190$ & 0.1184 \\
Intact-PTH $>102 \mathrm{pg} / \mathrm{mL}$ & 0.862 & $0.331-2.203$ & 0.7562 \\
Albumin $>4 \mathrm{~g} / \mathrm{dL}$ & 0.608 & $0.249-1.453$ & 0.2633 \\
Proteinuria $>0.57 \mathrm{~g} / \mathrm{gCr}$ & 0.779 & $0.308-1.923$ & 0.5895 \\
Hemoglobin $>12.4 \mathrm{~g} / \mathrm{dL}$ & 0.297 & $0.099-0.821$ & 0.0188 \\
Non-HDL-Cholesterol $>134 \mathrm{mg} / \mathrm{dL}$ & 3.570 & $1.449-9.442$ & 0.0053 \\
Triglyceride $>137 \mathrm{mg} / \mathrm{dL}$ & 2.447 & $1.028-5.997$ & 0.0431 \\
Alfacalcidol $1 \mu \mathrm{g} / \mathrm{week}$ & 1.164 & $0.779-1.776$ & 0.4618 \\
\hline
\end{tabular}

Model adjusted $r^{2}=0.243$. Dependent variable: $25(\mathrm{OH}) \mathrm{D}$ deficiency $<15 \mathrm{ng} / \mathrm{m}$

treatment with vitamin $\mathrm{D}$ analogues on the serum $25(\mathrm{OH}) \mathrm{D}$ levels (22). Even though we showed a common policy for starting vitamin $\mathrm{D}$ analogue for CKD patients, we did not rule out the effect of the timing of vitamin D supplementation.

In conclusion, the prevalence of vitamin D deficiency was higher among the nondialyzed CKD patients, and the factors associated with this condition were diabetes and obesity. Given the possible benefits of maintaining adequate vitamin $\mathrm{D}$ status in $\mathrm{CKD}$, well designed interventional trials that take into account subgroups at high risk for vitamin D deficiency are needed to develop effective strategies for the pre- vention and treatment of vitamin D deficiency.

The authors state that they have no Conflict of Interest (COI).

\section{Acknowledgement}

This study was supported by a Grant-in-Aid from the Japan Promotion Society for Cardiovascular Diseases.

\section{References}

1. Mehrotra R, Kermah D, Budoff M, et al. Hypovitaminosis D in chronic kidney disease. Clin J Am Soc Nephrol 3: 1144-1151, 
2008.

2. Holick MF. Vitamin D deficiency. N Engl J Med 357: 266-281, 2007.

3. Ishimura E, Nishizawa $Y$, Inaba $M$, et al. Serum levels of 1,25-dihydroxyvitamin D, 24,25-dihydroxyvitamin D, and 25hydroxyvitamin D in nondialyzed patients with chronic renal failure. Kidney Int 55: 1019-1027, 1999.

4. National Kidney Foundation. KDOQI Clinical Practice Guidelines on Bone Metabolism and Disease in Chronic Kidney Disease. Am J Kidney Dis 42 (Suppl 3): S1-S201, 2003.

5. Mehrotra R, Kermah DA, Salusky IB, et al. Chronic kidney disease, hypovitaminosis D, and mortality in the United States. Kidney Int 76: 977-983, 2009.

6. Ravani P, Malberti F, Tripepi G, et al. Vitamin D levels and patient outcome in chronic kidney disease. Kidney Int 75: 88-95, 2009.

7. Petchey WG, Howden EJ, Johnson DW, Hawley CM, Marwick T, Isbel NM. Cardiorespiratory fitness is independently associated with 25-hydroxyvitamin D in chronic kidney disease. Clin J Am Soc Nephrol 6: 512-518, 2011.

8. Jassal SK, Chonchol M, von Muhlen D, Smits G, Barrett-Connor E. Vitamin D, parathyroid hormone, and cardiovascular mortality in older adults: the Rancho Bernardo Study. Am J Med 123: 1114-1120, 2010.

9. Yamashita T, Yoshida T, Ogawa T, Tsuchiya K, Nitta K. Clinical outcomes in patients with chronic kidney disease: a 5-year retrospective cohort study at a University Hospital in Japan. Clin Exp Nephrol 15: 831-840, 2011.

10. Imai E, Matsuo S, Makino H, et al. Chronic Kidney Disease Japan Cohort study: baseline characteristics and factors associated with causative diseases and renal function. Clin Exp Nephrol 14: 558-570, 2010.

11. Holick MF. The influence of vitamin $\mathrm{D}$ on bone health across the life cycle. J Nutr 135: 2726S-2727S, 2005.

12. Arunabh S, Pollack S, Yeh J, et al. Body fat content and 25hydroxyvitamin D levels in healthy women. J Clin Endocrinol
Metab 88: 157-161, 2003.

13. Vilarrasa N, Maravall J, Estepa A, et al. Low 25-hydroxyvitamin $\mathrm{D}$ concentrations in obese women: their clinical significance and relationship with anthropometric and body composition variables. J Endocrinol Invest 30: 653-658, 2007.

14. Tzotzas T, Papadopoulou FG, Tziomalos $\mathrm{K}$, et al. Rising serum 25-hydroxy-vitamin D levels after weight loss in obese women correlate with improvement in insulin resistance. J Clin Endocrinol Metab 95: 4251-4257, 2010.

15. Lumb GA, Mawer EB, Stanbury SW. The apparent vitamin D resistance of chronic renal failure: a study of the physiology of vitamin D in man. Am J Med 50: 421-444, 1971.

16. Chiu CK, Chu A, Go VLW, et al. Hypovitaminosis D is associated with insulin resistance and cell dysfunction. Am J Clin Nutr 79: 820-825, 2004.

17. Pittas AG, Lau J, Hu FB, et al. The role of vitamin D and calcium in type 2 diabetes. A systematic review and meta-analysis. J Clin Endocrinol Metab 92: 2017-2029, 2007.

18. Bouillon R, Carmeliet G, Verlinden L, et al. Vitamin D and human health: lessons from vitamin $\mathrm{D}$ receptor null mice. Endocr Rev 29: 726-776, 2008.

19. Xiang W, Kong J, Chen S, et al. Cardiac hypertrophy in vitamin $\mathrm{D}$ receptor knockout mice: role of the systemic and cardiac reninangiotensin systems. Am J Physiol Endocrinol Metab 288: E125E132, 2005.

20. Chonchol M, Scragg R. 25-Hydroxyvitamin D, insulin resistance, and kidney function in the Third National Health and Nutrition Examination Survey. Kidney Int 71: 134-139, 2007.

21. Zehnder D, Quinkler M, Eardley KS, et al. Reduction of the vitamin D hormonal system in kidney disease is associated with increased renal inflammation. Kidney Int 74: 1343-1353, 2008.

22. Kandula P, Dobre M, Schold JD, Schreiber MJ Jr, Mehrotra R, Navaneethan SD. Vitamin D supplementation in chronic kidney disease: a systematic review and meta-analysis of observational studies and randomized controlled trials. Clin J Am Soc Nephrol 6: 50-62, 2011.

\section{(C) 2012 The Japanese Society of Internal Medicine http://www.naika.or.jp/imindex.html}

